\title{
The May 18, 1998 Indian Nuclear Test Seismograms at station NIL
}

W. R. Walter, A. J. Rodgers, D. Bowers, N. Selby

April 12, 2005 
This document was prepared as an account of work sponsored by an agency of the United States Government. Neither the United States Government nor the University of California nor any of their employees, makes any warranty, express or implied, or assumes any legal liability or responsibility for the accuracy, completeness, or usefulness of any information, apparatus, product, or process disclosed, or represents that its use would not infringe privately owned rights. Reference herein to any specific commercial product, process, or service by trade name, trademark, manufacturer, or otherwise, does not necessarily constitute or imply its endorsement, recommendation, or favoring by the United States Government or the University of California. The views and opinions of authors expressed herein do not necessarily state or reflect those of the United States Government or the University of California, and shall not be used for advertising or product endorsement purposes.

This work was performed under the auspices of the U.S. Department of Energy by University of California, Lawrence Livermore National Laboratory under Contract W-7405-Eng-48. 


\section{The May 18, 1998 Indian Nuclear Test Seismograms at station NIL}

William R. Walter, Arthur J. Rodgers - LLNL

David Bowers and Neil Selby - Blacknest

The last underground nuclear tests were conducted by India and Pakistan in May 1998. Although the Comprehensive Test Ban Treaty has not entered force, an International Monitoring System (IMS), established by the treaty is nearing completion. This system includes 170 seismic stations, a number of them originally established by IRIS. The station IRIS station NIL (Nilore, Pakistan) is close to a planned IMS primary station and recorded some very interesting seismograms from the May 18, 1998 Indian test. We carefully calibrated the path to NIL using a prior Mw 4.4 that occurred on April 4, 1995 about $110 \mathrm{~km}$ north of the Indian test site. We used joint epicentral location techniques along with teleseismic $\mathrm{P}$ waves and regional surface waves to fix the epicenter, depth, mechanism and moment of this event. From these we obtained a velocity model for the path to NIL and created explosion synthetic seismograms to compare with the data. Interestingly the observed Rayleigh waves are reversed, consistent with an implosion rather than an explosion source. The preferred explanation is that the explosion released tectonic stress near the source region, which can be modeled as a thrust earthquake of approximate $\mathrm{Mw}$ 4.0 plus a pure explosion. This tectonic release is sufficient to completely dominate the Rayleigh waves and produce the observed signal (Walter et al. 2005). We also examined the explosion at high frequencies of $6-8 \mathrm{~Hz}$ where many studies have shown that relative $\mathrm{P} / \mathrm{S}$ amplitudes can discriminate explosions from a background of earthquakes (Rodgers and Walter, 2002). Comparing with the April 4 1995 earthquake we see the classic difference of relatively large $\mathrm{P} / \mathrm{S}$ values for the explosion compared to the earthquakes despite the complication of the large tectonic release during the explosion.

\section{References:}

Rodgers, A. J. and W. R. Walter, Seismic discrimination of the May 11, 1998 Indian nuclear test with short-period regional data from station NIL (Nilore, Pakistan), Pure Appl. Geophys., 159, 679-700, 2002.

Walter, W. R., D. Bowers, N. Selby, A. Rodgers and D. Porter, Tectonic Release from the May 11, 1998 Indian Nuclear Tests, LLNL report UCRL-JRNL-202983-DRAFT (to be submitted in 2005).
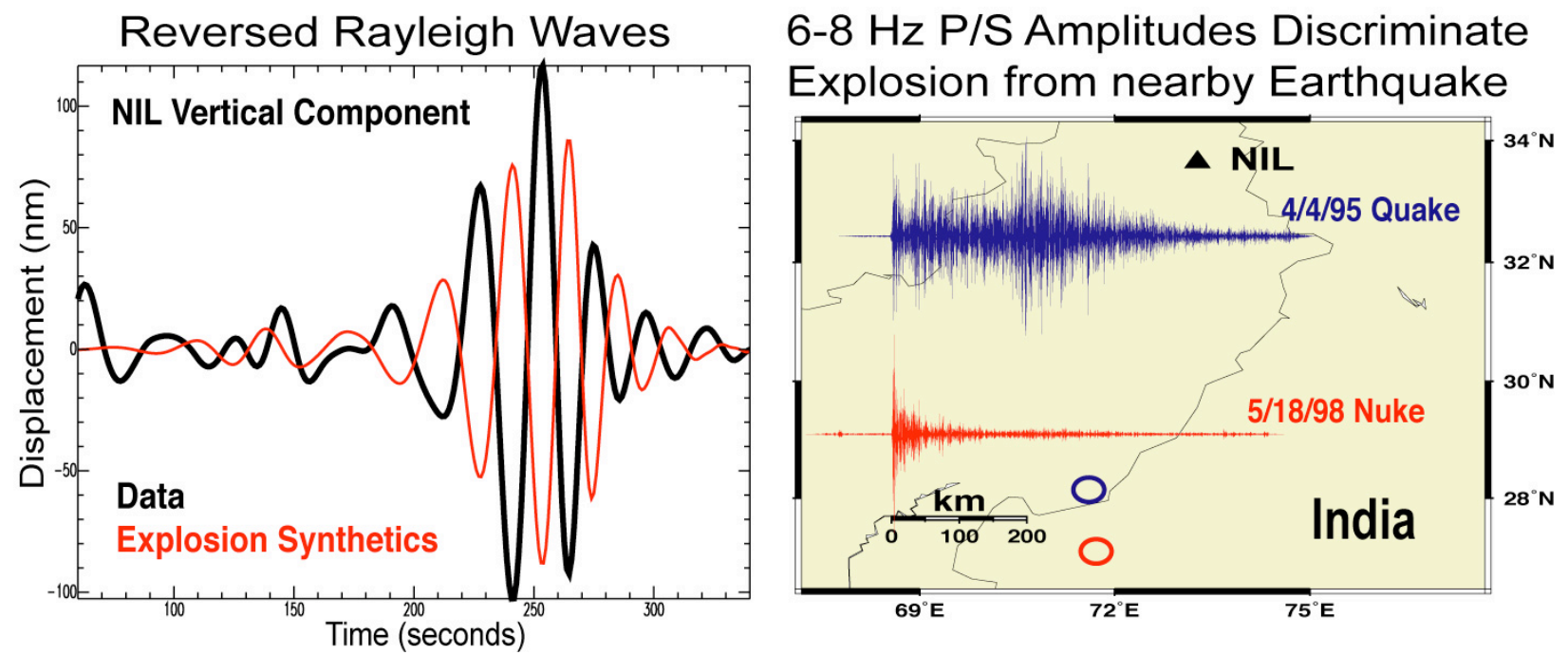